\title{
Study on Comparison between EVA Index and Traditional Accounting Profit Index in Value Assessment of Listed Banks
}

\author{
Wei Di \\ Department of Accounting \\ School of Economics and Management \\ Jiangsu University of Science and Technology \\ Zhenjiang, China 212003
}

\author{
Yu Zhang \\ Department of Accounting \\ School of Economics and Management \\ Jiangsu University of Science and Technology \\ Zhenjiang, China 212003
}

\begin{abstract}
Taking the 2014 data of 16 listed banks as study sample and combining with the actual situation of each index, this article distributes the indexes and builds the regression model to compare the differences between the EVA index and traditional accounting profit index and explain the value of matters related. Through comparative study it is discovered that the EVA-based indexes have quite strong explanatory power, even stronger than the traditional profit indexes to certain degree; however, limited by the range of explanation, EVA index still cannot fully replace the traditional indexes.
\end{abstract}

Keywords-listed bank; EVA; MVA; traditional accounting profit index

\section{INTRODUCTION}

The performance evaluation of listed company, as an important basis to learn its operation and management situation, is presented by net profit, asset-liability ratio and other key indexes. Nevertheless, lacking of consideration of equity cost, these traditional indexes neither result in complete evaluation nor comprehensively reflect the actual condition of the company. Therefore, Stem-Stewart Management Consulting Company, based on thorough analysis of the traditional indexes, initially presented the conception of EVA in 1980s. EVA index makes up for the deficiencies of traditional profit indexes and the profit it evaluates is some economic profit, in fact more comprehensive, for it can better include the debt capital cost and equity capital cost. [1]

EVA puts the shareholder interests in the first place, so that to a certain degree, it effectively avoids detrimental actions to shareholder interests. EVA points out that the true value created by enterprises refers to the value of net profit deducting the weighted average cost of capital (WACC). Only when the EVA is positive value does it mean the yield created by enterprise exceeds the minimum attractive rate of return as shareholders required and only fully taking capital which can bring shareholders with profits into consideration to make shareholders acquire a higher yield than risk ratio in risk market, can we say it is a material improvement. Apparently, EVA takes various costs of equities into consideration,

[Chinese library classification No.] F275

[Document code] A particularly the cost of equity capital; hence, it is more reasonable and feasible to evaluate enterprise value with EVA index, which agrees with the accomplishment of shareholder interests as well. Certainly, matters concerning scope of regulation exist between EVA index and traditional profit index, and which index is more suitable for shareholders as reference of investment is required to deeply discuss in this article.

In October 2003, China Construction Bank started to carry out EVA-based performance assessment system; in 2005 and 2006, the Agricultural Bank of China and Industrial and Commercial Bank of China started to carry out economic capital management method and EVA-based comprehensive performance assessment method hot on the heels; regarding it as a chance, more and more commercial banks started to try new indicators for performance assessment, so as to optimize the existing assessment system and realize the optimization of assessment mechanism. In this article, it takes the 16 listed banks as objects of study, market value added (MVA) as variable being explained and the economic indexes of banks' traditional accounting profit indexes as explanatory variable, so as to compare their explanatory abilities of value of listed banks through analyzing the relationship between EVA variable and value of listed banks as well as the relationship between the accounting profitability index and the value of listed banks.

\section{CURRENT RESEARCH SituAtion AT HOME AND ABROAD}

Scholars at home and abroad fully study the EVA index and traditional profitability index, but they have different research perspectives and conclusions.

Debdas Raksht (2006) selects the financial data from 19982002 of Indian Dabur Company as sample to compare and analyze the economic value added, rate of income on investment and earnings per share. The result shows that EVA index can better reflect the company's true profitability and take the whole capital cost of the company into consideration; while, the traditional profitability index apparently cannot fully reflect the true situation of the company.[2] 
Wang Chengyong (2011) takes 890 companies of Shanghai and Shenzhen stock market as samples to compare EVA index and the traditional accounting profitability indexes, e.g. cash flow, residual income, etc. by virtue of the level and change models. The following conclusion is reached: in terms of information content, EVA index is inferior to traditional accounting profitability index.[3]

Liu Xiaodong, Du Huan and Chen Jun (2015) subdivide the traditional profitability index and conduct monadic regressive analysis while subdivide EVA index and conduct multiple linear regressive analysis. It is discovered through research that EVA index has a stronger explanatory ability of enterprise value than the traditional accounting profitability index.[4]

Lin Xiang (2015) summarizes the profitability data of 12 listed companies and conducts fitting analysis on the traditional profitability index and EVA index of the 12 listed companies by means of multiple linear regressions. It is discovered through analysis that both indexes can well build multiple linear regression model; however, it is discovered through comparison that EVA index has higher degree of fitting and is more applicable to building multiple linear regression model.[5]

Mirela (2015) selects the 2013 financial data of 12 companies listed in Romania securities exchange, including their debt paying ability, return on invested capital, liabilities and cost ratio of average investment capital, to research and analyze the correlation between EVA index and indexes above, and the result shows that the correlation between EVA and liabilities and cost ratio of average investment capital is negative; however, the correlation between EVA and debt paying ability and return on invested capital is apparently positive. [6]

Thus it can be seen that, currently, lots of researches take listed companies as samples while a few aim at a certain industry; however, the business performance of a company is greatly related to the industry it belongs to, so that items need to require in EVA calculation process are different. Hence, by taking 16 listed banks as research samples, we chose bank industry to carry out the comparative research between EVA index and traditional performance evaluation indicators, avoiding influences of different levels of competition in different industries on company performance.

\section{RESEARCH DESIGN}

\section{A. Research Hypothesis}

Upon researches, Uyemura Rantor and PettiT found that the correlation between MVA and EVA was the strongest. MVA refers to the balance between the market value of all the assets and the total amount of capital invested by shareholders and creditors in the enterprise, which is the expected response of the market to the ability of enterprises' gaining the future EVA, and is equal to the expected present value of the future EVA. The higher the MVA indicates the more wealth the enterprise creates for its shareholders. Therefore, the assumptions as follows are put forward:

There is a significant positive correlation between EVA and MVA.
As a vital index of value creation and management, EVA comprehensively reflects the operating efficiency and capital operation ability of management personnel. Uyemura Rantor and PettiT found that compared with other financial index, EVA's interpretation of MVA is significantly higher. Therefore, the assumptions as follows are put forward:

EVA index system is superior to traditional accounting profit index in the ability of explaining MVA.

\section{B. Sample Selection and Data Sources}

This article selects 16 listed banks in Shenzhen and Shanghai as samples, 4 state-owned banks: Band of China, Industrial and Commercial Bank of China, China Construction Bank and Agricultural Bank of China; 12 joint-stock banks: Bank of Communications, Beijing Bank, Huaxia Bank, Ningbo Bank, China Merchants Bank, Shanghai Pudong Development Bank, China Everbright Bank, Minsheng Bank, CITIC Bank, Ping An Bank, Industrial Bank and Bank of Nanjing.

Because of the tedious calculation of EVA index, it involves the adjustment of several accounting items. Some scholars in China collect the original data and adjust the accounting items which need to be adjusted, and then calculate the value of EVA. However, many foreign scholars directly use the data provided by Stern Stewart Company's EVA database to study and this method not only saves time, but also avoids the repeated labor. Moreover, it makes the research develop to a deeper level. All kinds of research are based on the same data, so the conclusion is more comparable. Therefore, the EVA and MVA value in this article are from China Tai'an database and 2014annual report data is from the huge tide information network. This article uses spss23.0 version software as the analysis software.

\section{Research Variables}

The research variables are mainly composed of three parts: market value-added, economic value-added and accounting index system; the market value-added (MVA) is used as the explained variable, referring to the difference between the stock market values of a listed company and the book value of the company's stock and debt which is adjusted. [7] In other words, market value-added is the wealth that is created to shareholders by the total company's capital through stock accumulation, that is, the difference between the realized value and the accumulated capital input. Compared with EVA, MVA reaction is a kind of performance evaluation of a long term and external market.

Market value added $=$ discounted value of future economic value added. "Table I" 
TABLE I. MEANing OF STUdY VARIABLES

\begin{tabular}{|l|l|l|l|}
\hline \multicolumn{1}{|c|}{$\begin{array}{c}\text { Variable } \\
\text { Name }\end{array}$} & \multicolumn{1}{|c|}{$\begin{array}{c}\text { Variable } \\
\text { Symbol }\end{array}$} & \multicolumn{1}{|c|}{ Variable Meaning } & \multicolumn{1}{|c|}{$\begin{array}{c}\text { Variable } \\
\text { Attribute }\end{array}$} \\
\hline $\begin{array}{l}\text { Market Value- } \\
\text { Added }\end{array}$ & MVA & $\begin{array}{l}\text { Market Value - Invested } \\
\text { Capital }\end{array}$ & $\begin{array}{l}\text { Explained } \\
\text { Variable }\end{array}$ \\
\hline $\begin{array}{l}\text { Economic } \\
\text { Value-Added }\end{array}$ & EVA & $\begin{array}{l}\text { Net Operating Profit after } \\
\text { Tax - Invested Capital * } \\
\text { Capital Cost Ratio }\end{array}$ & $\begin{array}{l}\text { Explanatory } \\
\text { Variable }\end{array}$ \\
\hline Net Profit & NP & $\begin{array}{l}\text { Gross Profit * (1 - Income } \\
\text { Tax Rate) }\end{array}$ & $\begin{array}{l}\text { Explanatory } \\
\text { Variable }\end{array}$ \\
\hline $\begin{array}{l}\text { Return On } \\
\text { Equity }\end{array}$ & ROE & $\begin{array}{l}\text { Net profit / Stockholders' } \\
\text { Total Equity }\end{array}$ & $\begin{array}{l}\text { Controlled } \\
\text { Variable }\end{array}$ \\
\hline $\begin{array}{l}\text { Return On } \\
\text { Assets }\end{array}$ & ROA & Net profit /All Assets & $\begin{array}{l}\text { Controlled } \\
\text { Variable }\end{array}$ \\
\hline $\begin{array}{l}\text { Earnings Per } \\
\text { Share }\end{array}$ & EPS & Surplus / General Capital & $\begin{array}{l}\text { Controlled } \\
\text { Variable }\end{array}$ \\
\hline $\begin{array}{l}\text { Cost-Income } \\
\text { Ratio }\end{array}$ & CI & $\begin{array}{l}\text { Operating Expenses / } \\
\text { Operating Revenues }\end{array}$ & $\begin{array}{l}\text { Controlled } \\
\text { Variable }\end{array}$ \\
\hline $\begin{array}{l}\text { Non- } \\
\text { Performing } \\
\text { Loan Ratio }\end{array}$ & NPL & $\begin{array}{l}\text { Loan provision Rate/ } \\
\text { Provision Coverage }\end{array}$ & $\begin{array}{l}\text { Controlled } \\
\text { Variable }\end{array}$ \\
\hline
\end{tabular}

IV. EMPIRICAL RESULTS AND ANALYSIS

\section{A. Descriptive Statistics and Analysis}

TABLE II. DESCRIPTIVE STATISTICS

\begin{tabular}{|l|l|l|l|l|l|}
\hline & $\begin{array}{l}\text { Number } \\
\text { of Cases }\end{array}$ & $\begin{array}{c}\text { Minimum } \\
\text { Value }\end{array}$ & $\begin{array}{c}\text { Maximum } \\
\text { Value }\end{array}$ & $\begin{array}{c}\text { Average } \\
\text { Value }\end{array}$ & Variance \\
\hline $\begin{array}{l}\text { Market Value- } \\
\text { Added }\end{array}$ & 16 & $3.16 \mathrm{e}+10$ & $3.04 \mathrm{e}+12$ & $7.23 \mathrm{e}+11$ & $8.99 \mathrm{e}+23$ \\
\hline $\begin{array}{l}\text { Economic Value } \\
\text { Added }\end{array}$ & 16 & $8.99 \mathrm{e}+09$ & $1.19 \mathrm{e}+11$ & $3.74 \mathrm{e}+10$ & $1.58 \mathrm{e}+21$ \\
\hline Net Profit & 16 & $5.66 \mathrm{e}+09$ & $2.76 \mathrm{e}+11$ & $7.93 \mathrm{e}+10$ & $7.28 \mathrm{e}+21$ \\
\hline Return On Equity & 16 & 0.1487 & 0.2121 & 0.1862 & 0.000 \\
\hline Return On Assets & 16 & 0.010 & 0.014 & 0.0116 & 0.000 \\
\hline Earnings Per Share & 16 & 0.55 & 2.52 & 1.4225 & 0.478 \\
\hline Cost-Income Ratio & 16 & 0.2312 & 0.3757 & 0.2990 & 0.002 \\
\hline $\begin{array}{l}\text { Non-Performing } \\
\text { Loan Ratio }\end{array}$ & 16 & 0.0086 & 0.0154 & 0.0112 & 0.000 \\
\hline
\end{tabular}

"Table II" shows that the above two indicators are both positive number, and the condition of EVA index indicates that earnings are still higher than the opportunity cost of their capital for the unit capital in the 16 listed banks in 2014. It further shows that these 16 listed banks can create real value for shareholders, and their profitability is true at no expense of the interests of shareholders.

The maximum, minimum and variance of the EVA index are lower than the net profit, which objectively shows the limitation of the traditional profit index. In other words, the traditional profit index used by these 16 banks excludes the capital stock and there is no deduction for this data, which makes the final settlement results are always higher than the EVA value of the equity capital cost.

Meanwhile, it also manifests that the cost of equity capital of listed banks in China is usually greater than the cost of debt capital. If the equity cost is not taken into consideration when accounting the management results of enterprises on the basis of traditional accounting standards, the role of financial leverage can give full play, and the management layer can create more value for shareholders. However, once the cost of equity capital is added into the total capital cost of enterprises, when the sum of the cost of equity capital and debt capital cost of the enterprise is greater than the operating income, EVA will counteract the all excess profits brought by the role of financial leverage.

\section{B. Correlation Analysis}

To better understand the correlation degree among variables, it requires conducting correlation analysis of known variables. The purpose of correlation analysis is to learn about the correlation degree among variables, so we may eliminate some variables in the process of analyzing. In the process of this research, we will use "Pearson" method to analyze the correlation index. "Table III"

TABLE III. CORRELATION COEFFICIENT SHEET

\begin{tabular}{|c|c|c|c|c|c|c|c|c|}
\hline & MVA & EVA & $\mathbf{N P}$ & ROI & ROA & EPS & CI & NPL \\
\hline$\overline{\mathrm{MVA}}$ & 1 & & & & & & & \\
\hline EVA & $\begin{array}{l}0.983 * * * \\
(0.000)\end{array}$ & 1 & & & & & & \\
\hline NP & $\begin{array}{l}-0.194 \\
(0.472)\end{array}$ & $\begin{array}{l}-0.165 \\
(0.541)\end{array}$ & 1 & & & & & \\
\hline ROE & $\begin{array}{l}0.245 \\
(0.360)\end{array}$ & $\begin{array}{l}0.203 \\
(0.450)\end{array}$ & $\begin{array}{l}-0.158 \\
(0.560)\end{array}$ & 1 & & & & \\
\hline ROA & $\begin{array}{l}0.756 * * * \\
(0.001)\end{array}$ & $\begin{array}{l}0.775 * * * \\
(0.000)\end{array}$ & $\begin{array}{l}-0.133 \\
(0.622)\end{array}$ & $\begin{array}{l}0.571 * * \\
(0.021)\end{array}$ & 1 & & & \\
\hline EPS & $\begin{array}{l}-0.555^{* *} \\
(0.026)\end{array}$ & $\begin{array}{l}-0.562 * * \\
(0.023)\end{array}$ & $\begin{array}{l}0.121 \\
(0.655)\end{array}$ & $\begin{array}{l}0.445 * \\
(0.084)\end{array}$ & $\begin{array}{l}-0.203 \\
(0.451)\end{array}$ & 1 & & \\
\hline CI & $\begin{array}{l}-0.112 \\
(0.681)\end{array}$ & $\begin{array}{l}-0.122 \\
(0.652)\end{array}$ & $\begin{array}{c}0.001 \\
(0.997)\end{array}$ & $\begin{array}{l}-0.194 \\
(0.471)\end{array}$ & $\begin{array}{l}-0.324 \\
(0.220)\end{array}$ & $\begin{array}{l}-0.187 \\
(0.488)\end{array}$ & 1 & \\
\hline NPL & $\begin{array}{l}0.462 * \\
(0.071)\end{array}$ & $\begin{array}{l}0.491 * \\
(0.054)\end{array}$ & $\begin{array}{l}0.103 \\
(0.705)\end{array}$ & $\begin{array}{l}-0.010 \\
(0.971)\end{array}$ & $\begin{array}{l}0.256 \\
(0.339)\end{array}$ & $\begin{array}{l}-0.606 * * \\
(0.013)\end{array}$ & $\begin{array}{l}0.281 \\
(0.291)\end{array}$ & 1 \\
\hline
\end{tabular}

Form the relative results of sample; we can see that the correlation coefficient between MVA and EVA is 0.983, which is the highest correlation coefficient in all explanatory variables. And at the $1 \%$ level, it shows that there is a positive and significant relationship between the MVA and EVA of the 16 listed banks. The correlation coefficient 
between MVA and NP is -0.194 , but this number does not pass the significance test, which shows that the relationship between them is not clear. The others are in the same way. From the perspective of correlation coefficient, the connection of MVA and EVA becomes closer, which shows that EVA has more advantages than the traditional accounting profit indicators in explaining the value of listed banks to some extent.

\section{Multivariate Regression Analysis}

Multiple regression analysis can be used to examine the joint influence degree of the influence of explanatory variables on dependent variables. Therefore, we construct the following model: $\mathrm{MVA}=\mathrm{b} 0+\mathrm{b} 1 \mathrm{EVA}+\mathrm{b} 2 \mathrm{NP}+\mathrm{b} 3 \mathrm{ROE}+\mathrm{b} 4 \mathrm{ROA}+\mathrm{b} 5 \mathrm{EPS}+\mathrm{b} 6 \mathrm{CI}+$ b7NPL, and the specific regression results are in "Table IV".

TABLE IV. MultiPle REgRession Results

\begin{tabular}{lllll}
\hline & Coefficient & T value & P value & F value \\
\hline Constant (Quantity) & & 0.227 & 0.826 & \\
Economic Value & $1.025 * * *$ & 9.197 & 0.000 & 4.578 \\
Added & 0.015 & 0.256 & 0.804 & 1.280 \\
Net Profit & $0.200 *$ & 1.932 & 0.089 & 3.951 \\
Return On Equity & -0.159 & -1.302 & 0.229 & 5.523 \\
Return On Assets & -0.161 & -1.449 & 0.185 & 4.528 \\
Earnings Per Share & -0.002 & -0.031 & 0.976 & 1.373 \\
Cost-Income Ratio & -0.096 & -1.195 & 0.266 & 2.390 \\
Non-Performing & R2=0.978 & & \\
Loan Ratio & Adjusted & & \\
\hline \multicolumn{5}{c}{ R2=0.959 } \\
\multicolumn{4}{c}{ Note: $1 .^{*}, *$ and $* *$ refer to the significance respectively in $1 \%, 5 \%$ and $10 \%$ level. }
\end{tabular}

From the above results, we can see that the regression equation is significant and model R2 is 0.978 and the adjusted R2 is 0.959 , which shows that the fitting effect of the model is good and the EVA index provides large incremental information in explaining the change of firm value. There is a certain relationship between the explanatory variables and MVA, but most of them do not pass the significance test and the coefficient of EVA pass the significance test, which shows that EVA has a significant impact on MVA. Under the circumstances of keeping other factor unchanged, EVA increases by $1 \%$ each, and the corresponding MVA will increase by $1.025 \%$. T value is used to explain the significance test of variables on the dependent variable. "Table IV" shows: the return on equity in traditional accounting profit index is the most significant, but the $9.197 \mathrm{~T}$ value of EVA is more significant, which further indicates that EVA index has important value as an index of enterprise performance evaluation.

\section{CONCLUSION AND SUGGESTION}

Taking the 16 listed banks as an example, this article analyzes the explanatory ability of EVA index and traditional accounting profit index on the market value added (MVA). Although it is of certain subjectivity on selected indexes for demonstrating the analysis model, still some information can be acquired from the results:
From the relativity and significance level of MVA and each performance evaluation index, we can see that the correlation coefficient of MVA and EVA is much larger and of great significance, which manifests that the explanatory ability of EVA to MVA is higher than other accounting profit indexes for MVA. It has some feasibility and rationality to use the EVA index to evaluate the value of listed banks. Based on the above-mentioned regression analysis, obviously EVA index has a better explanatory ability in revealing the above-mentioned problems. Certainly, EVA index is different from the traditional profit index, so there are some differences on explaining the relevant problems. EVA and traditional accounting profit evaluation index are based on the business finance report forms. In order to achieve short-term operating performance objectives, some enterprises may manipulate finance report forms. A sort of results can be reflected by the EVA index, while it is mainly the process shown by the traditional profit index, so they are complementary in a way. Therefore, we cannot take EVA index as the only assessment element, and should refine the evaluation index in accordance with the actual situation so that it can better play its role in the actual evaluation. Overall, EVA index is more suitable for measuring the value of listed banks compared to traditional accounting profit index.

At the same time, it also reveals the limitation of EVA index, and the traditional profit index still has high value in the aspect of evaluation. When enterprises introduce the EVA index, simultaneously, they should pay attention to the traditional accounting profit index(net profit, return on net assets and return on total assets etc.); when investors evaluate the value of enterprise, not only the EVA value, but the traditional accounting profit index should be paid attention by them; otherwise the conclusions may be inaccurate.

In conclusion, it is necessary and feasible to introduce EVA evaluation system. In the process of evaluating, the traditional index and EVA index should be subdivided and considered comprehensively to reveal the actual situation of the company from different levels. By regarding the economic added value as the evaluation target of enterprise, it can improve the capital cost consciousness of enterprise, encourage the management layer to create more value, and guide them to improve the core competitiveness by reasonable investment, improving management, promoting performance, expanding asset and adjusting capital structure, etc.

\section{REFERENCES}

[1] Zhao Hua, Yin Qin. The Explanatory Ability of EVA Index to the Market Value Added of Power Generation Enterprises -- Compared with Traditional Accounting Profit Index.[J]. Finance and Accounting Monthly, 2012(15):62-65.

[2] Debdas Rakshit. EVA Based Performance Measurement: A Case Study of Dabur India Limited. Vidyasagar University Journal of commerce.11(3), 2006:40-59.

[3] Wang Chengyong. Discussion on Performance Evaluation of Merger and Acquisition Based on EVA Index. [J]. Communication of Finance and Accounting, 2011(05):10-11. 
[4] Liu Xiaodong, Du Huan, Chen Jun. Application of EVA Index in the Stock Market of China. [J]. Statistics and Information Forum, 2015(03):65-69.

[5] Lin Xiang. Research on Enterprise Performance Evaluation Based on EVA Index -- Taking Petro China as an Example. [J]. Money China (Academic Edition), 2015 (08):38-39.

[6] Mirela, Determinant of the Economic Value Added in the case of Romanian companies listed on the Stock Exchange [J].financier, 2015, 1(8):100-108.

[7] Yao Shukun. A Study on the Impact of Diversification on Firm Performance. [D]. Tianjin University of Finance and Economics, 2013. 